\title{
Evaluation of Variability for Growth, Seed Yield and its Contributing Characters in Chilli Genotypes
}

\author{
Vijay Kumar Arya ${ }^{1}$, Sunita Bhandari ${ }^{2 *}$ and A.C. Mishra ${ }^{3}$ \\ ${ }^{1}$ State Department of Agriculture, Uttarakhand, India \\ ${ }^{2}$ Department of Agriculture, U.C.B.M.S. \& H, Dehradun, Uttarakhand, India \\ ${ }^{3}$ Department of Horticulture, Banda Agriculture University, U.P, India \\ *Corresponding author
}

\begin{tabular}{|l|}
\hline Ke y w o r d s \\
Chilli or hot pepper \\
(Capsicum annuum \\
L.), Solanaceae
\end{tabular}

\section{A B S T R A C T}

The present investigation was conducted during Kharif 2014 at vegetable research block of Veer Chandra Singh Garhwali Uttrakhand University of Horticulture and Forestry, Ranichauri Campus with 14 genotypes of Chilli. The experiment was laid out in randomized block design with three replications. Observation were recorded on seed yield and growth parameters viz., days to $50 \%$ flowering, number of primary branches, number of secondary branches, plant height $(\mathrm{cm})$, ripe fruit length $(\mathrm{cm})$, ripe fruit girth $(\mathrm{cm})$, ripe fruit weight $(\mathrm{g})$, number of red fruit per plant, red fruit yield per plant $(\mathrm{g})$, number of seed per fruit, seed yield per plant $(\mathrm{g})$, seed yield $(\mathrm{q} / \mathrm{ha})$. A great extent of variability was observed among the various genotypes for characters studied. Analysis of variance for seed yield and quality characters revealed significant difference among the genotypes for all the characters. The genotype UHFC 12-6 revealed maximum values for seed yield (4.99 $\mathrm{g} / \mathrm{plant}$ and $2.46 \mathrm{q} / \mathrm{ha})$ and ripe fruit weight $(5.30 \mathrm{~g})$, whereas UHFC 12-4 exhibited best performance for red ripe fruit yield per plant $(62.78 \mathrm{~g})$ and number of ripe fruit per plant (17.44). The genotype UHFC $12-5$ was promising for number of primary branches per plant (5.60) was noted in UHFC 12-1. Therefore, genotypes UHFC 12-6, UHFC 12-4, UHFC 12-5 and UHFC 12-1 could be used in future breeding programme for improvement in most of the ripe fruit yield, seed yield, and seed quality parameters in chilli.

\section{Introduction}

Chilli or hot pepper (Capsicum annuum L.) belonged to family Solanaceae has a chromosome number of $2 n=2 x=24$. It is indigenous to South America and was first introduced chilli in India from Brazil by Portuguese toward the end of $15^{\text {th }}$ century (Basu and Krishna, 2003). Chilli is an often cross pollinated crop and, therefore, exhibits wide variability for different qualitative and quantitative traits (Tanksley, 1984). The red dry chillies is known for nutritional value with moisture $(10.00 \mathrm{~g})$, protein $(15.00 \mathrm{~g})$, fat $(6.20$ g), minerals $(6.10 \mathrm{~g})$, fibres $(30.20 \mathrm{~g})$, carbohydrates $(31.60 \mathrm{~g})$, energy $(246.00$ Kcal), calcium (160.00 mg), iron $(2.30 \mathrm{mg})$, carotene $(160.00 \mathrm{mg})$, thiamine $(0.930 \mathrm{mg})$, riboflavin $(0.430 \mathrm{mg})$, vitamin $\mathrm{C}(50.00 \mathrm{mg})$, niacin $(9.50 \mathrm{mg})$, sodium $(14.00 \mathrm{mg})$, potassium $(530.00 \mathrm{mg})$, phytin phosphorus $(71.00 \mathrm{mg}$ ) per $100 \mathrm{~g}$ of edible matter 
(Anonymous, 2007). Variability among the genotype can also be assessed on account of seed yield, its contributing characters and seed quality parameters. A genotype performing better for seed yield in a particular agroclimate indicates its better adaptability to that particular agroclimate conditions and designing breeding programme involving that well adapted genotype may lead to convergence of desirable genes to progeny. Variability in seed quality parameters like seed boldness, germinability, seedling vigour etc. may also lead to useful conclusions. An aggregate account of seed yield and quality indicates may prove to be informative for initializing a breeding programme to evolve population with ability to produce more quantity of vigorous seeds.

The information on studies on seed yield and quality parameters in chilli genotypes is available in the temperate region. Poor adaptability to sub optimal low temperature in rain fed condition at high altitude and lack of promising high yielding cultivar are major constraints for bringing up chilli cultivation in hill region of Uttarakhand at commercial scale. Collection of evaluation of germplasm for adaptability to suboptimal low temperature, moisture stress and excessive rainfall condition in relation to seedling ability and seed quality traits may offer like Uttarakhand hills. The present investigation, therefore include following objective; to study variability for seed yield and its contributing characters in chilli genotypes.

\section{Materials and Methods}

The present investigation entitled "Studies on seed yield and quality parameters in chilli (Capsicum annuum L.) genotypes" was carried out during the kharif season of 2014 at Vegetable Research Block of Department of Vegetable Science, Veer Chandra Singh Garhwali Uttarakhand University of
Horticulture and Forestry, Ranichauri Campus, TehriGarhwal, Uttarakhand. The experiment was conducted in the Randomized Block Design (R.B.D.) with three replication during kharif season of 2014. Therefore, there is an urgent need to select or develop hardy and cold tolerant superior genotypes for mid and higher hills. Present investigation was carried out on 14 genotypes of chilli and the results obtained on various seed yield contributing quantitative characters and seed quality traits. The data collected on different quantitative and qualitative traits were processed for the analysis of variance as per suggested the procedure by Panse and Sukhatme (1967). The table for analysis of variance (ANOVA) was set as explained by Gomez and Gomez (1983).

\section{Results and Discussion}

\section{Days to $50 \%$ flowering (DAS)}

Days to $50 \%$ flowering ranged from 68.66 DAS to 81.31 DAS. The minimum days to $50 \%$ flowering was noted in Kashmir Long (68.66 DAS) followed by UHFC 12-2 (70.33 DAS) UHFC 12-6 (71.00 DAS) and UHFC 13-2 (71.66 DAS). PusaSadabahar and UHFC 13-1 exhibited maximum days to $50 \%$ flowering (81.33 DAS). The mean value of the population was 74.19 DAS. Early flowering genotypes like Kashmiri Long, UHFC 12-2, UHFC 12-6, and UHFC 13-2 could be used in chilli improvement programmes for earliness. Similar results on variability in days to flowering have also been reported by Farhad et al., (2008) from 61.17 DAS to 84.93 DAS, Tembhurne et al., (2008) 63.0 DAS to 82.0 DAS, days and Amit et al., (2014) from 70.53 DAS to 94.13 DAS in chilli.

\section{Number of primary branches per plant}

The number of primary branches per plant ranged from 3.66 to 5.60. The highest number 
of primary branches were observed in UHFC 12-5 (5.60) followed by statistically at par values in UHFC 12-4 (5.46), PusaJwala (5.26), UHFC 13-3 (5.13), UHFC 13-1 (5.03) and UHFC 13-2 (4.73). The lowest number of primary branches per plant was noted in PusaSadabahar (3.66). The general mean of population was 4.86 . Primary branches decide the growth habit of plants. Higher numbers of primary branches indicate spreading nature of the plants whereas lower number represents straight growth nature. Corresponding to the findings of present investigation, variability in number of primary branches per plant have also been reported by Smith and Basavaraja (2006) from 3.50 to 12.70 , Ukkund et al., (2007) from 2.05 to 6.65 and Tembhurne et al., (2008) from 4.33 to 5.73 in chilli.

\section{Number of secondary branch per plant}

There was significant difference among the genotypes for number of secondary branches per plant. The genotype UHFC 13-2 had highest number of secondary branches per plant (5.23) followed by UHFC 12-1 (5.16), UHFC 12-3 (5.03), PusaJwala (5.00), UHFC 13-7 (4.93), UHFC 13-1 (4.86), Kashmiri Long (4.80), PusaSadabahar (4.73) and UHFC 12-2 (4.66) which were statistically at par. The lowest number of secondary branches per plant was noticed in UHFC 12-6 (3.86). The general mean of population was (4.70). Similar results on variability in number of branches in chilli have also been reported by Smith and Basavaraja (2006) from 11.40 to 24.80, Ukkund et al., (2007) from 2.80 to 6.15 and Tembhurne et al., (2008) from 3.6 to 8.83.

\section{Plant height (cm)}

The plant height of the genotypes ranged between $23.75 \mathrm{~cm}$ to $38.85 \mathrm{~cm}$ with a significant difference (Table 1). The plant height was observed maximum in UHFC 13-3 $(38.85 \mathrm{~cm})$. Five other genotypes with statistically at par values of plant height to UHFC 13-3 were UHFC 12-1 $(36.17 \mathrm{~cm})$, UHFC 13-2 (35.73 cm), Kashmiri Long $(34.88 \mathrm{~cm})$, UHFC $13-1(32.38 \mathrm{~cm})$ and UHFC 12-6 $(31.88 \mathrm{~cm})$. The plant height was observed to be lowest in genotype PusaJwala $(23.75 \mathrm{~cm})$. The mean value of population for plant height was $30.66 \mathrm{~cm}$. The genotypes with more plant height could be utilized for enhancing the growth and development by increasing the plant response to sunlight and soil inputs by the way of photosynthesis and translocation resulting in gain in vegetative development in the plants. These results were in confirmity with those obtained by Smith and Basavaraja (2006) who reported plant height of $79.27 \mathrm{~cm}$, Ukkund et al., (2007) from $40.40 \mathrm{~cm}$ to $110 \mathrm{~cm}$, Farhad et al., (2008) from $20.06 \mathrm{~cm}$ to $67.95 \mathrm{~cm}$ ), Chaudhary et al., (2013) from $40.20 \mathrm{~cm}$ to $61.40 \mathrm{~cm}$ and Amit et al., (2014) $89.97 \mathrm{~cm}$ plant height in chilli.

\section{Ripe fruit length (cm)}

Difference among the genotypes with respect to ripe fruit length was significant which ranged from $4.96 \mathrm{~cm}$ to $11.39 \mathrm{~cm}$ (Table 1). The maximum value of ripe fruit length was observed in UHFC 13-1 $(11.39 \mathrm{~cm})$ followed by Kashmiri Long $(10.20 \mathrm{~cm})$ which were $a t$ par to each other. The next group with at par ripe fruit length were UHFC 13-3 $(9.56 \mathrm{~cm})$, UHFC $13-2(8.8 \mathrm{~cm})$ and PusaSadabahar $(8.38 \mathrm{~cm})$. The minimum value of ripe fruit length was observed in UHFC 12-5 $(4.96 \mathrm{~cm})$. The population mean for this trait was found to be $7.49 \mathrm{~cm}$. Ripe fruit length was mainly due genetic makeup of the genotypes and may also be influenced by agronomical practices proving its $\mathrm{G} \times \mathrm{E}$ expression. Corresponding results on variability in fruit length of genotypes have also been reported by Smith and Basavaraja, (2007) from $2.65 \mathrm{~cm}$ to 13.48 $\mathrm{cm}$, Ukkund et al., (2007) from $3.45 \mathrm{~cm}$ to $14.05 \mathrm{~cm}$, Tembhurne et al., (2008) from 7.73 
$\mathrm{cm}$ to $11.78 \mathrm{~cm}$ and Pandit and Adhikary (2014) from $4.23 \mathrm{~cm}$ to $9.74 \mathrm{~cm}$.

\section{Ripe fruit girth $(\mathrm{cm})$}

The difference among the genotypes with respect to the ripe fruit girth was found to be significant (Table 1). Fruit girth ranges between $0.80 \mathrm{~cm}$ and $2.13 \mathrm{~cm}$. The maximum ripe fruit girth was found in UHFC 13-1 (2.13 $\mathrm{cm})$ followed by statistically at par values in Kashmiri Long (2.06 cm), UHFC 13-4 (2.00 $\mathrm{cm})$, UHFC 13-3 $(1.97 \mathrm{~cm})$ and UHFC 13-2 $(1.90 \mathrm{~cm})$.

The lowest value of ripe fruit girth was found in PusaSadabahar $(0.80 \mathrm{~cm})$. The population mean for this character was observed to be $1.68 \mathrm{~cm}$. Fruit girth and many other fruit yield attributing traits like fruit number, length etc. are a measure of ability of genotype to synthesize and convert into the food materials. Higher values for these traits represent source efficiency of particular genotype. Similar results on variability in fruit girth have also been reported by Ukkund et al., (2007) from $0.52 \mathrm{~cm}$ to $1.91 \mathrm{~cm}$, Farhad et al., (2008) from $0.49 \mathrm{~cm}$ to $1.69 \mathrm{~cm}$ and Chattopadhyay et al., (2011) from $0.33 \mathrm{~cm}$ to $2.77 \mathrm{~cm}$ in chilli genotypes.

\section{Number of ripe fruits per plant}

The data on number of red ripe fruits per plant in chilli is quite different to that obtained in the crop grown for green chillies as periodical picking of green fruits promotes subsequent bearing leading to more number of green fruits per plant. In contrary, the fruits once borne are left unpicked till ripening in the seed crop and therefore further fruiting is checked leading to comparatively lower number of fruits per plant. The difference among the genotypes with respect to the number of red ripe fruits per plant was highly significant (Table 2) which varied from 6.80 to 17.44 . Significantly higher number of red ripe fruits per plant was observed in UHFC 12-4 (17.44) followed by UHFC 12-2 (14.47) and UHFC 13-3 (13.39). Minimum number of red ripe fruits per plant was registered in UHFC 13-4 (6.80). The population mean for this trait was observed to be 10.45. In this investigation variation in the number of red ripe fruits per plant was mainly due to difference in genetic makeup of the genotypes.

The results were in accordance with those of Ravihunje et al., (2007) (23.93 to 29.31 fruits per plant) and Farhad et al., (2008) (5.76 to 24.2 fruits per plant). However, comparatively higher number of red fruits per plant was noticed by Chattopadhyay et al., (49.18) and Pandit and Adhikary (2014) (22.50 to 86.35) in chilli.

\section{Ripe fruit weight $(\mathrm{g})$}

There was a highly significant difference among 14 genotypes with respect to red ripe fruit weight (Table 2). The maximum and significantly higher fruit weight was registered in UHFC 12-6 (5.30 g) followed by Kashmiri Long (4.60 g) and UHFC 13-2 (3.83 g). Minimum value for ripe fruit weight was observed in UHFC 12-2 (1.36 g). The population mean was $3.22 \mathrm{~g}$. The fruit weight at ripe stage includes the weight of pericarp and seeds. Therefore, higher value of red fruit weight may or may not lead to high seed yield. However, this may have influence on both ripe fruits yield and seed yield per plant. As against the finding of the present investigation, comparatively lower range of fruit weight have been reported by Ravihunje et al., (2007) from $1.05 \mathrm{~g}$ to $1.08 \mathrm{~g}$ and Tembhurne et al., (2008) from $0.72 \mathrm{~g}$ to 1.12 g. However, comparable variability in fruit weight was noticed by Amit et al., (2014) from $1.71 \mathrm{~g}$ to $5.16 \mathrm{~g}$ and Pandit and Adhikary (2014) from $1.53 \mathrm{~g}$ to $2.82 \mathrm{~g}$ in chilli genotypes. 


\begin{tabular}{|c|c|c|c|c|c|c|c|}
\hline SI. No. & Character & $\begin{array}{l}\text { Days to } \\
50 \% \\
\text { flowering } \\
\text { (DAS) }\end{array}$ & $\begin{array}{l}\text { No of } \\
\text { primary } \\
\text { branches } \\
\text { per plant }\end{array}$ & $\begin{array}{l}\text { No of } \\
\text { secondary } \\
\text { branches } \\
\text { per plant }\end{array}$ & $\begin{array}{l}\text { Plant } \\
\text { height } \\
\text { (cm) }\end{array}$ & $\begin{array}{l}\text { Ripe } \\
\text { fruit } \\
\text { length } \\
\text { (cm) }\end{array}$ & $\begin{array}{l}\text { Ripe fruit } \\
\text { girth } \\
(\mathrm{cm})\end{array}$ \\
\hline 1 & UHFC 12-1 & 72.33 & 5.26 & 5.16 & 36.17 & 5.88 & 1.59 \\
\hline 2 & UHFC 12-2 & 70.33 & 5.13 & 4.66 & 30.57 & 6.51 & 1.70 \\
\hline 3 & UHFC 12-3 & 74.00 & 4.63 & 5.03 & 26.13 & 7.11 & 1.77 \\
\hline 4 & UHFC 12-4 & 74.33 & 5.46 & 4.40 & 27.27 & 6.63 & 1.62 \\
\hline 5 & UHFC 12-5 & 75.00 & 5.60 & 4.63 & 28.18 & 4.96 & 1.80 \\
\hline 6 & Kashmiri Long & 68.66 & 4.66 & 4.80 & 34.88 & 10.20 & 2.06 \\
\hline 7 & UHFC 13-2 & 71.66 & 4.73 & 5.23 & 35.73 & 8.83 & 1.90 \\
\hline 8 & UHFC 13-3 & 75.00 & 5.13 & 4.33 & 38.85 & 9.56 & 1.97 \\
\hline 9 & UHFC 13-4 & 74.00 & 4.66 & 4.13 & 34.40 & 5.94 & 2.00 \\
\hline 10 & PusaJwala & 76.33 & 5.26 & 5.00 & 23.75 & 6.95 & 1.46 \\
\hline 11 & PusaSadabahar & 81.33 & 3.66 & 4.73 & 24.32 & 8.38 & 0.80 \\
\hline 12 & UHFC 12-6 & 71.00 & 4.13 & 3.86 & 31.88 & 6.38 & 1.42 \\
\hline 13 & UHFC 13-1 & 81.33 & 5.03 & 4.86 & 32.38 & 11.39 & 2.13 \\
\hline \multirow[t]{5}{*}{14} & UHFC 13-7 & 73.66 & 4.66 & 4.93 & 24.78 & 6.18 & 1.33 \\
\hline & Mean & 74.19 & 4.86 & 4.70 & 30.66 & 7.49 & 1.68 \\
\hline & C.V. & 1.92 & 11.46 & 7.43 & 10.25 & 12.46 & 8.12 \\
\hline & S.E. & 0.82 & 0.32 & 0.20 & 1.81 & 0.53 & 0.07 \\
\hline & C.D.5\% & 2.39 & 0.93 & 0.58 & 7.13 & 1.56 & 0.23 \\
\hline
\end{tabular}

\begin{tabular}{|l|l|l|l|l|l|l|l|}
\hline SI. No. & \multicolumn{1}{|c|}{ Character } & $\begin{array}{l}\text { Ripe } \\
\text { fruit } \\
\text { weight } \\
(\mathrm{g})\end{array}$ & $\begin{array}{l}\text { No of } \\
\text { ripe } \\
\text { fruits per } \\
\text { plant }\end{array}$ & $\begin{array}{l}\text { Ripe } \\
\text { fruit } \\
\text { yield per } \\
\text { plant }(\mathbf{g})\end{array}$ & $\begin{array}{l}\text { No of } \\
\text { seeds } \\
\text { per fruit }\end{array}$ & $\begin{array}{l}\text { Seed } \\
\text { yield per } \\
\text { plant (g) }\end{array}$ & $\begin{array}{l}\text { Seed yield } \\
\text { (q/ha) }\end{array}$ \\
\hline $\mathbf{1}$ & UHFC 12-1 & 3.06 & 11.40 & 34.98 & 71.33 & 3.93 & 1.94 \\
\hline $\mathbf{2}$ & UHFC 12-2 & 3.80 & 8.47 & 32.22 & 67.00 & 3.64 & 1.79 \\
\hline $\mathbf{3}$ & UHFC 12-3 & 1.36 & 14.47 & 19.81 & 48.33 & 3.72 & 1.84 \\
\hline $\mathbf{4}$ & UHFC 12-4 & 3.60 & 17.44 & 62.78 & 44.66 & 4.46 & 2.20 \\
\hline $\mathbf{5}$ & UHFC 12-5 & 1.93 & 8.12 & 15.67 & 72.00 & 3.16 & 1.57 \\
\hline $\mathbf{6}$ & Kashmiri Long & 4.60 & 12.33 & 56.76 & 86.00 & 4.52 & 2.23 \\
\hline $\mathbf{7}$ & UHFC 13-2 & 3.83 & 7.47 & 28.63 & 56.00 & 3.79 & 1.87 \\
\hline $\mathbf{8}$ & UHFC 13-3 & 2.10 & 13.39 & 28.11 & 82.33 & 3.25 & 1.60 \\
\hline $\mathbf{9}$ & UHFC 13-4 & 3.50 & 6.80 & 23.76 & 48.00 & 3.27 & 1.62 \\
\hline $\mathbf{1 0}$ & PusaJwala & 3.83 & 7.53 & 28.90 & 79.33 & 2.25 & 1.12 \\
\hline $\mathbf{1 1}$ & PusaSadabahar & 2.20 & 9.86 & 21.68 & 54.66 & 3.12 & 1.54 \\
\hline $\mathbf{1 2}$ & UHFC 12-6 & 5.30 & 10.22 & 54.25 & 68.00 & 4.99 & 2.47 \\
\hline $\mathbf{1 3}$ & UHFC 13-1 & 2.16 & 9.61 & 20.80 & 80.33 & 2.89 & 1.43 \\
\hline $\mathbf{1 4}$ & UHFC 13-7 & 3.86 & 9.25 & 35.76 & 89.33 & 2.53 & 1.25 \\
\hline & Mean & $\mathbf{3 . 2 2}$ & $\mathbf{1 0 . 4 5}$ & $\mathbf{3 3 . 1 5}$ & $\mathbf{6 7 . 6 6}$ & $\mathbf{3 . 5 3}$ & $\mathbf{1 . 7 5}$ \\
\hline & C.V. & $\mathbf{8 . 1 3}$ & $\mathbf{2 . 6 2}$ & $\mathbf{9 . 5 0}$ & $\mathbf{5 . 4 7}$ & $\mathbf{1 5 . 0 8}$ & $\mathbf{1 5 . 0 6}$ \\
\hline
\end{tabular}




\section{Number of seeds per fruit}

The mean performance for the number of seeds per fruit indicated significant difference across the genotypes (Table 2). The overall range of number of seeds per fruit varied from 44.66 to 89.33 . The maximum value for this trait was observed in the case of UHFC 13-7 (89.33) which was significantly higher than that in other genotypes. The other genotypes with higher number of seeds per fruit were Kashmiri Long (86.00), UHFC 13-3 (82.33), UHFC 13-7 (80.33) and PusaJwala (79.33), whereas the minimum value was observed in UHFC 12-4 (44.66). The number of seeds per fruit greatly influence seed yield. The result of the present investigation indicates a wide range of variability in seed setting ability of various genotypes in terms of number of seeds per fruit. Similar results on variability in number of seeds per fruits have also been reported by Natesh et al., (2005) from 78.3 to 85.7, Ravihunje et al., (2007) from 70.99 to 80.57, Farhad et al., (2008) from 37.97 to 114.00, Pandit and Adhikary (2014) from 32.51 to 110.84 and Amit et al., (2014) from 40.24 to 113.85 in chilli.

\section{Ripe fruit yield per plant (g)}

In seed production crop of the chilli, red ripe fruit yield accounts for ultimate seed as well as dried chilli or powder yield. Corresponding to the other traits, genotypic differences were also noted for red ripe fruit yield per plant which varied from $15.67 \mathrm{~g}$ to $62.78 \mathrm{~g}$. The mean values for this traits showed that UHFC 12-4 produced highest quantity of red fruits per plant $(62.78 \mathrm{~g})$, which was significantly higher than that in other genotypes. The Kashmiri Long (56.76 g) and UHFC 12-6 $(54.25 \mathrm{~g})$ were other high ripe fruit yielding genotypes. The lowest value of red ripe fruits yield per plant was found in UHFC 12-5 $(15.67 \mathrm{~g})$ while the mean value of population was recorded to be $33.15 \mathrm{~g}$. The genotypes viz., UHFC 12-4, UHFC 12-6 and Kashmiri Long may be utilized for increasing the red ripe fruit yield in breeding programmes. The findings of present investigation on red fruit yield per plant could be compared with reports of earlier workers viz., Ravihunje et al., (2007) who observed $20.86 \mathrm{~g}$ to $24.33 \mathrm{~g}$ ripe fruit yield per plant, Tembhurne et al., (2008) from $34.6 \mathrm{~g}$ to $100.2 \mathrm{~g}$, Chattopadhyay et al., (2011) from $44.22 \mathrm{~g}$ to $8.36 \mathrm{~g}$, Chaudhary et al., (2013) from $65.40 \mathrm{~g}$ to 308.22 g yield and Amit et al., (2014) from $24.73 \mathrm{~g}$ to $102.24 \mathrm{~g}$ ripe fruit yield per plant in chilli.

\section{Seed yield per plant (g)}

The character seed yield per plant was found to be varying across the genotypes and it ranged from $2.25 \mathrm{~g}$ to $4.99 \mathrm{~g}$. The maximum seed yield per plant was registered by UHFC 12-6 (4.99 g) followed by Kashmiri Long (4.52 g) and UHFC 12-4 (4.46 g) which were at par. The minimum seed yield per plant was recorded in PusaJwala $(2.25 \mathrm{~g})$. The mean value of the population was $3.53 \mathrm{~g}$ (Table 2). High or low seed setting is governed by genetic constitution of the genotypes to a greater extent however; the role of environment cannot be ignored. High seed yield in certain genotypes indicates their suitability in climatic conditions prevailing in temperate hills of Uttarakhand. Variability in seed yield per plant has also been reported by Natesh et al., (2005) from $1.31 \mathrm{~g}$ to $6.31 \mathrm{~g}$ and Priya et al., (2013) from $7.16 \mathrm{~g}$ to $8.88 \mathrm{~g}$ in chilli.

\section{Seed yield (q/ ha)}

Seed yield per hectare significantly varied from $1.11 \mathrm{q} / \mathrm{h}$ a to $2.46 \mathrm{q} / \mathrm{h}$. The highest seed yield was recorded in UHFC 12-6 (2.46 q/ha) followed by Kashmiri Long ( $2.22 \mathrm{q} / \mathrm{ha}$ ) and UHFC 12-4 (2.20 q/ha) with statistically at par values. The lowest seed yield was 
observed in PusaJwala (1.11 q/ha). The general mean of population for seed yield per hectare was $1.74 \mathrm{q} / \mathrm{ha}$ (Table 2). Comparable range of variability in seed yield per hectare was noticed by Natesh et al., (2005) (0.416q/ha to $2.71 \mathrm{q} / \mathrm{ha})$ and Ravihunje et al., (2007) (1.114q/ha) but Priya et al., (2014), reported comparatively higher seed yield i.e. $6.72 q$ /ha to $7.65 q /$ ha in chilli.

Highest quantity of seed yield per plant and per hectare in UHFC 12-6 (4.99 $\mathrm{g}$ and 2.46 $\mathrm{q} / \mathrm{ha}$, respectively) was accompanied with maximum fruit weight $(5.30 \mathrm{~g})$ and moderate number of ripe fruits per plant. It indicated that for improving seed yield potential of a genotype, selection for fruit weight should be preferred as compared to number of ripe fruits per plant. However, the latter should be treated as dependable character while working with objective to improve red fruit yield in chilli as the genotype UHFC 12-4 with higher red ripe fruit yield per plant $(62.78 \mathrm{~g})$ was accompanied with highest number of ripe fruits per plant (17.44) and moderate fruit weight $(3.60 \mathrm{~g})$. From the results of the present investigation it could be concluded that out of fourteen genotypes of chilli UHFC 12-6 registered maximum values for seed yield (4.99 g/plant and $2.46 \mathrm{q} / \mathrm{ha})$, and ripe fruit weight $(5.30 \mathrm{~g})$.Whereas UHFC 12-4 exhibited best performance for red ripe fruit yield per plant (62.78 g) and number of ripe fruit per plant (17.44). The genotype UHFC 12-5 was promising for number of primary branches per plant (5.60). Therefore, genotypes UHFC 12-6, UHFC 12-4, UHFC 12-5 and UHFC 12-1 could be used in future breeding programme for improvement in most of the ripe fruit yield, seed yield, and seed quality parameters in chilli.

\section{References}

Amit, K., Ahad, I., Kumar, V. and Thakur, S. 2014. Genetic variability and correlation studies for growth and yield characters in chilli (Capsicum annuum L.). J. Spice and Aromatic Crops. 23(2): 170-177.

Anonymous. 2007. Statistical data base National Institute of Nutrition, Hyderabad, pp- 9.

Basu, K.S. and Kirshna, D. E. A. 2003. Capsicum. Medicinal and Aromatic Plant. Industrial Profiles, London.

Chattopadhyay, A., Sharanagi, A. B., Dai, N. and Dutta, S. 2011. Diversity of genetics recourses and genetic association analysis of green and dry chilles of eastern India). Chilean $J$. Agric. Res. 71 (3): 156-160.

Chaudhary, A., Kumar, R. and Solankey, S.S. 2013. Estimation on heterosis for yield and components in chilli (Capsicum annuum L.). African J. of Biotech. 12 (47): 6605-6610.

Farhad, M., Hasanuzzaman, M., Biswas, B.K., Azad, A.K. and Arifuzzaman, M. (2008) Reliability of yield contributing characters for improving yield potential in chilli (Capsicum annuum L.). International Journal Sustainable Crop Production. 3(3): 30-38.

Gomez, K. A. and Gomez, A. A. 1983. Statistical Procedure for Agriculture Research. $2^{\text {nd }}$ edition. John Wiley and Sons, New York. Pp.357-427.

Natesh, N., Vyakaranahal, B.S., Shekhargouda, M. and Deshpande, V. K. 2005. Effect of stratified harvesting of fruit on seed yield and quality of chilli. Karnatka J. Agric Sci. 18 (2): 505-507.

Pandit, M. K. and Adhikary, S. 2014. Variability and heritability estimates in some reproductive character and yield in chilli (Capsicum annuum L.). International J. of Plant \& Soil Sci. 3(7): 845-853.

Panse, V.G. and Sukhatme, P.V. 1967. Statistical Method for Agriculture 
Workers. $2^{\text {nd }}$ edition, ICAR publication. New Delhi. Pp.381.

Priya, K., Deshpande. V. K. and Kumar, H. B. 2013. Influence of fertilizer level and seedling age on growth, flowering, seed yield and seed quality of parental line of chilli hybrid HCH- 9646. A Quarterly J. Life Sci. 10(1): 110-114.

Ravihunje, B. S., Vyakarnahal and Jagadeesh, R. C. 2007. Influence of drying method of fruits on seed quality in chilli (Capsicum annuum L.). Karnataka J. Agric. Sci. 20(2): 269-271.

Smith, R. P. and Basavaraja, N. 2006. Variability and correlation studies in chilli (Capsicum annuum L.). Karnatka J. Agric. Sci. 19(4): 888-891.

Tanksley, S. D. 1984. High rates of crosspollination in chilli pepper. Hort. Science. 19: 580-582.

Tembhurne, B. V., Ravanappa and Kuchanur, P.H. 2008. Varietal performance, genetic variability and correlation studies in chilli (Capsicum annuиm L.). Karnataka J. Agric. Sci. 21(4): 541-543.

Ukkund, K. C., Madalageri, M. B., Patil, M. P., Mulage, R. and Kotikal, Y. K. 2007.Variability studies in chilli (Capsicum annuum L.). Karnataka J. Agric. Sci. 20(1):102-104.

\section{How to cite this article:}

Vijay Kumar Arya, Sunita Bhandari and Mishra, A.C. 2018. Evaluation of Variability for Growth, Seed Yield and Its Contributing Characters in Chilli Genotypes. Int.J.Curr.Microbiol.App.Sci. 7(10): 1118-1125. doi: https://doi.org/10.20546/ijcmas.2018.710.123 